\title{
Cyfrowy kult przodków - aplikacja Deep Nostalgia jako nowa forma mediatyzacji pamięci religijnej
}

\begin{abstract}
The paper analyzes a particular example of the expansion of popular culture through a specific mediatization of old photographs and paintings, which consists in transforming works of art into short, simulated videos. This new technology was interpreted using religious categories with references to ancestor worship and cultural studies with the paradigm of memory studies. It was theorized that the new processes of mediatization are changing the religious memory of society.
\end{abstract}

Keywords: mediatization, religious memory, ancestor worship, photography

\section{Wstęp. Mediatyzacja kultury i religii}

$\mathrm{P}$ rocesy mediatyzacji trwale zmieniają obrazy współczesnej kultury, z czym wiąże się przede wszystkim konstatacja, iż coraz więcej tekstów kultury zostaje zapośredniczonych przez nowe media ${ }^{1}$. Udostępnianie treści medialnych w przestrzeni Internetu nie jest czynnością tylko techniczną, lecz ma pewne konsekwencje w budowaniu określonych przekazów i obrazów. Treści te są filtrowane przez interfejsy, a także strukturyzowane w różnych algorytmach i programach, według

${ }^{1}$ H.A. Campbell, When Religion Meets New Media, Routledge, London-New York 2010, ss. 9-10. 
oczekiwań użytkowników. W konsekwencji, jak spostrzega Marek Kaźmierczak, prowadzi to do zanikania wyraźnych granic między kulturowym centrum a jego marginesami, preferowaniem nawyków percepcyjnych użytkowników medium, ponieważ łączenie poszczególnych faktów odbywa się w sposób wysoce arbitralny i indywidualny ${ }^{2}$. W jeszcze dalszych efektach ta sytuacja kulturowa powoduje, iż w obszarze zmediatyzowanym same przekazy sprawiają wrażenie nietrwałych oraz niestabilnych, a teksty kulturowe ulegają łatwym modyfikacjom i translacjom, czego przykładem są memy religijne ${ }^{3}$.

W historii mediów tradycyjnych, ważne miejsce odgrywała fotografia. Jest to medium, którego początki sięgają pierwszych dekad XIX wieku. Za pierwszą udaną fotografię uznaje się Widok z okna w Le Gras (1826), wykonaną przez francuskiego wynalazcę Josepha Nicéphora Niépcego. Dzieło było zrobione w technice heliografii, stanowiło zatem graficzną odbitkę reprodukcji. Jest sporne, czy ten negatywowy obraz nożna uznać za fotografię sensu stricto. W kolejnych dekadach popularne stały się dagerotypy, a wyraźną i kolorową fotografię udało się wykonać w latach 60. XIX wieku. Pierwszym konfliktem, z którego zachowała się dobrej jakości dokumentacja fotograficzna, była amerykańska wojna secesyjna. Niemal sto lat później rozwinie się fotografia cyfrowa, która dominuje obecnie w tym medium ${ }^{4}$. Jest kwestią filozoficznej i estetycznej dyskusji, czy istotą fotografii jest wierne odzwierciedlanie rzeczywistości, czy raczej aktywizowanie sfery wyobrażeniowej oraz zmienianie ludzkiego spojrzenia na świat ${ }^{5}$. Z perspektywy teologicznej w kulturze chrześcijańskiej obrazy stawały się przedmiotami sakralnej afirmacji (jak ikony czy zachodnie malarstwo sakralne). Sama fotografia bywa przedmiotem krytyki. Według Witolda Kaweckiego może być zbyt dominująca w obszarze kultury współczesnej, odsłaniać sacrum bądź redukować treść fotografii do sfery czysto technicznej i użytkowej ${ }^{6}$. Nie opowiadając się za którymś z tych założeń, można jednocześnie przyjąć, za Katarzyną Tracewicz, że tak jak media internetowe zmieniają współczesne doświadczanie świata w aspekcie przestrzennym - przez możliwość docierania do miejsc odległych fizycznie oraz odbiór wydarzeń z innych obszarów ${ }^{7}$ - tak medium fotograficzne umożliwia użytkownikom pamięciowe reminiscencje sięgające ostatnich dwustu lat.

${ }^{2}$ M. Kaźmierczak, Auschwitz w Internecie. Przedstawienia Holokaustu w kulturze popularnej, Wydawnictwo Naukowe UAM, Poznań 2012, ss. 194-195.

3 J. Iwanicki, Memofania kultury. Zjawisko memów religijnych, „Humaniora. Czasopiosmo Intyernetowe 2018, $\mathrm{nr}$ 1(21).

${ }^{4}$ A. Briggs, P. Burke, Społeczna historia mediów. Od Gutenberga do Internetu, tłum. J. Jedliński, Wydawnictwo Naukowe PWN, Warszawa 2015, ss. 220-222.

5 J.P. Hudzik, Wykłady z filozofii mediów, Wydawnictwo Naukowe PWN, Warszawa 2017, ss. 234-235.

${ }^{6}$ W. Kawecki, Zobaczyć wiarę. Studium obrazu postrzeganego jako komunikacja wiary z perspektywy teologii kultury i teologii mediów, Homo Dei, Kraków 2013, s. 19.

${ }^{7}$ K. Tracewicz, Media a religijność i moralność badanej młodzieży, Wydział Teologii Uniwersytetu Warmińsko-Mazurskiego w Olsztynie, Olsztyn 2015, s. 33. 
W niniejszym artykule zanalizowany zostanie szczególny przykład ekspansji kultury popularnej przez specyficzną mediatyzację dawnych fotografii oraz malarstwa, polegającą na przekształcaniu tych dzieł w krótkie, symulowane filmiki. Następnie z tej egzemplifikacji wyprowadzone zostaną refleksje religioznawcze i kulturoznawcze.

\section{Deep Nostalgia - nowa forma mediatyzacji pamięci}

Przywoływany przykład kulturowy jest nową technologią, polegająca na ożywianiu zdjęć. Produkt został opracowany przez MyHeritage, międzynarodową platformę działającą głównie w obszarze internetu, specjalizującą się w projektach genealogicznych, służących do badania historii rodziny. Dotychczas korporacja oferowała technologie ulepszania i kolorowania zdjęć archiwalnych, programy służące do budowania skomplikowanych drzew genealogicznych czy bazy danych z zarchiwizowanymi rekordami i testami DNA ${ }^{8}$.

Aplikacja Deep Nostalgia jest narzędziem wprowadzonym do zasobów Internetu pod koniec 2020 roku. Ideą tego programu jest realistycznie ożywianie twarzy widocznych na archiwalnych zdjęciach poprzez tworzenie krótkich filmów, o dość wysokiej jakości, zbudowanych na realizmie ruszającej się głowy. W programie wbudowano kilka sterowników, które konfigurowane są na algorytmach ustalających określone sekwencje ruchów i gestów. Ożywiona twarz może poruszać głową, spoglądać na wprost widza, mrugać oczami, a także uśmiechać się. W ten sposób fotografia staje się krótkim filmikiem, trwającym kilkanaście sekund, który można oglądać wielokrotnie. Wykorzystana może być zarówno czarno-biała, jak i kolorowa fotografia. Przy czym stworzony dynamiczny obraz z założenia nie posiada dźwięku, aby uniknąć ewentualnych nadużyć z tworzeniem fałszywych filmów z żywymi ludźmi. Efekt końcowy tworzy zatem symulację tego, jak osoba widoczna na zdjęciu poruszałaby się i wyglądałaby, gdyby została zarejestrowana na filmie. Pomysł oparty jest na technice rekonstrukcji filmów przy użyciu uczenia maszynowego z zastosowaniem pewnych ulepszeń wgranych zdjęć o niskiej jakości (polegających na zwiększaniu rozdzielczości i wyostrzaniu widocznej twarzy). Funkcja programu może symulować również fragmenty głowy, które nie są widoczne na oryginalnym zdjęciu (na przykłąd uszy lub zęby).

Twórcy aplikacji, oprócz intencji wynikających z chęci osiągnięcia zysku ze sprzedaży oryginalnego programu, w różny sposób tłumaczą samą, nieco osobliwą, ideę ożywania zdjęć rodzinnych. Użyte jest określenie „podróż badawcza”, łączące przeszłość, teraźniejszość i przyszłość. W innym miejscu pojawia się wypowiedź twórców, iż funkcja nowej aplikacji ma cele nostalgiczne, a więc zamierzeniem projektu jest przywracanie do życia ukochanych przodków. Projekt skierowany

\footnotetext{
${ }^{8}$ MyHeritage, https://www.myheritage.pl/deep-nostalgia [dostęp: 30.6.2021].
} 
jest więc przede wszystkim do osób posiadających albumy rodzinne lub zdjęcia bliskich osób, które nie żyją. Jednocześnie MyHeritage zauważa, iż funkcje programu Deep Nostalgia mogą być odbierane jako „magiczne”, a nawet nienaturalne i kontrowersyjne. Nie stoi to jednak na przeszkodzie, by zachęcać użytkowników do wgrywania starych zdjęć do aplikacji i udostępniania ich w mediach społecznościowych.

W niektórych materiałach z serwisu nagrane są również reakcje osób, które oglądają zdjęcia swoich zmarłych bliskich. Ich emocje świadczą o tym, iż odbierają ożywione wizerunki na fotografiach, jako bliskie realizmowi poruszania się tej postaci, we własnej pamięci indywidualnej użytkownika. Korzystający z aplikacji Deep Nostalgia używają programu nie tylko do ożywania swoich prywatnych zdjęć rodzinnych. W dostępnych na YouTubie zasobach filmowych można zobaczyć niecodzienne zbiory postaci, których przedstawienia fotograficzne, różnej jakości, zostały poddane obróbce w medialnym projekcie. Znalazły się tu różne historyczne postacie, żyjące w XIX i XX wieku, takie jak: Abraham Lincoln, Maria Skłodowska-Curie, Grigorij Rasputin, Anne Frank, Martin Luther King i wiele innych ${ }^{9}$. Interesujące estetycznie są zwłaszcza te ożywione fotografie z osobami, po których nie zachowały się prawdziwe nagrania filmowe, odzwierciedlające ich symulowane ruchy ciała.

Omówiony program nosi widoczne znamiona nowej formy mediatyzacji pamięci. Abstrahując od jego technicznych rozwiązań, lecz koncentrując się na kulturowych i religijnych rezultatach, ten rodzaj ożywiania zdigitalizowanych fotografii może implikować dalsze zmiany nie tylko w konwergentnych mediach, ale także we wrażliwości i przeżywaniu pamięciowym przeszłości przez człowieka. Nowe technologie sprawiają, że wyobrażenia, do niedawna obecne raczej w literaturze science-fiction, stają się realne. Ożywanie zmarłych twarzy, o wysokim stopniu realizmu, może wywoływać różne odczucia wśród użytkowników i odbiorców, a także samych badaczy kultury medialnej. Można tutaj podążać tropami apokaliptycznymi, wskazując - jak Rafał Ilnicki - na powstanie technoanamnezy, mogącej oznaczać wolę przypominania w warunkach radykalnej technicyzacji świata, a także uporczywe ponawianie przypomnienia przez podmioty ludzkie i nie-ludzkie ${ }^{10}$ - w tym drugim przypadku rynek, który wprowadza nowy rodzaj technicznej pamięci, proponując użytkownikom wyobrażanie sobie tego, jak mogli się poruszać ich znani bądź nieznani protoplaści.

910 Historical Personalities Animated with Deep Nostalgia, http://www.youtube.com/ watch?v=251pfVoGBUA [dostęp: 30.6.2021].

${ }^{10}$ R. Ilnicki, Filozofia i science fiction: technoanamneza, Wydawnictwo WNS UAM, Poznań 2014, s. 27. 


\section{Cyfrowy kult przodków}

W omawianym przykładzie mediatyzacji pamięci znalazły się również próby internautów „ożywiania” wizerunków osób kojarzonych z religią. W ten sposób animowano obrazy przedstawiające Jezusa z przedstawieniem Najświętszego Serca czy poddano obróbce w Deep Nostalgia domniemaną rekonstrukcję twarzy Jezusa, opartą na uzasadnionym przekonaniu badawczym, iż miał on semicki wygląd osoby z terenów dzisiejszego Izraela. Nadto w różnorodnych zasobach YouTube można znaleźć próby „ożywiania” postaci świętych z dzieł malarskich. Program Deep Nostalgia „czyta” również wizerunki postaci w formie rzeźb (np. greckich lub rzymskich herm). Jednak efekty estetyczne i realistyczne takich prób animacji wizerunków osób są dyskusyjne. Aplikacja jest stworzona z myślą przede wszystkim o fotografii, jako głównym źródle pozyskiwania materiałów, choć próbuje współpracować z różnymi przedstawieniami wyrażonymi starszymi środkami artystycznymi.

Użytkownicy zmediatyzowanego projektu korzystają z niego przynajmniej w dwóch przypadkach: próbach ożywiania fotografii swoich bliskich zmarłych, jak i czynnościach edukacyjnych bądź rozrywkowych polegających na animowaniu w programie przedstawień znanych osób z historii i kultury. Dostępne zasoby wskazują zatem na to, że w różny sposób można interpretować owe zmediatyzowane obrazy. W kontekście religioznawczym zasadne może się okazać - wskazując na to, że celem projektu Deep Nostalgia wedle jego twórców, jest nawiązanie więzi ze zmarłymi bliskimi - iż mamy do czynienia z cyfrowym kultem przodków.

W literaturze religioznawczej istnieją różne przypadki historycznego kultu przodków. Przykłady najstarszych praktyk zawierają wierzenia afrykańskie. Utrzymuje się w nich, iż duchy przodków są pozbawione cielesnej powłoki, jednak byty te nadal zachowują się jak żywi i przebywają razem z pozostałymi ludźmi (choć w niektórych plemionach mogą przybierać postacie zwierzęce). Duchy te utrzymują swoje wcześniejsze osiągnięcia, w tym na przykład uzyskane godności i tytuły za życia, a także świadomość tego, kim były wcześniej. Istotny w tych wierzeniach jest praprzodek, który dał początek całemu rodowi. Nie wszyscy ze zmarłych zasługują na pamięć plemienia, na przeszkodzie może stać jakiś hańbiący czyn za życia. Duchy przodków wymagają karmienia, mogą nadal być głodne i oczekują w tym zakresie wsparcia od żyjącej rodziny. Istot tych jest wiele, każdy ród ma swoje duchy, z którymi powinien utrzymywać łączność. Lekceważenie tych duchów może prowadzić do różnych nieszczęść wśród żyjących, w tym wypadków czy chorób. Uzyskanie ich względów jest przedmiotem różnych czynności magicznych i religijnych, w których biegli mogą być plemienni szamani. Przekonanie o istnieniu duchów przodków, z którymi należy zachować więź oraz dobre kontakty 
(pamięć o bezpośrednich przodkach z reguły kończy się na piątym pokoleniu), jest w tradycyjnych wierzeniach afrykańskich dość powszechne ${ }^{11}$.

Elementy wierzeń skoncentrowanych na kulcie przodków można także odnaleźć w azjatyckich religiach - konfucjanizmie i szintoizmie. Chińska religia konfucjonistyczna, o dość wysokim stopniu racjonalizmu, zapewne jednak wchłonęła wcześniejsze praktyki, odwołujące się do organizacji plemiennej wczesnego społeczeństwa chińskiego z X wieku p.n.e. Wówczas król-szaman posiadał władzę magiczną, pozwalającą mu pośredniczyć między światem ludzi a światem bogów i duchów. Poprzez czynności wróżbiarskie król mógł sondować, jaka jest wola przodków, także w odniesieniu do jego decyzji związanych z rządzeniem. Zatem i tutaj kontakt z własnymi przodkami dynastycznymi konieczny był dla zachowania ciągłości ze światem boskim (założyciele dynastii często podlegali deifikacji). Tak praktykowany kult przodków, podobnie jak w wierzeniach afrykańskich, stwarzał możliwość ustabilizowania świata jako przestrzeni i czasu mającego atrybuty porządku oraz zrozumiałości ${ }^{12}$. Także w Japonii wiara w kult przodków była jedną z najważniejszych praktyk w religii szintoistycznej. Duchy zmarłych w tym systemie przebywają blisko świata żywych, szukając sposobności, aby przejść przez cienką szczelinę oddzielającą oba stany egzystencji. Stąd również bogata tradycja folklorystyczna w Japonii, przestrzegająca i zachęcająca do właściwych obrzędów, w sytuacji gdy dana osoba zmarła na skutek nagłego nieszczęścia (zwłaszcza morderstwa), i duch pozostaje w afekcie, oczekując zadośćuczynienia za popełniony przez sprawcę czyn. Gniewne duchy mogły również nękać ludność, jeśli swoje życie zakończyły na skutek epidemii czy klęski żywiołowej. Z czasem te duchy, jeśli ich oczekiwania zostały zaspokojone w czynnościach sakralnych, mogły stać się duchami opiekuńczymi kami, zatem ich natura mogła ulec zmianie, także w nowym stanie egzystencji. Kult przodków nadal jest ważnym składnikiem tradycyjnej japońskiej kultury i wiąże się z przekonaniem, że o zmarłych należy pamiętać i ich szanować, także zapraszając na świąteczne uczty. Wiąże się z tym pogląd, zgodnie z którym przodek rodziny cały czas pozostaje w pobliżu i interesuje się sprawami żywych ${ }^{13}$.

W zachodniej tradycji religijnej kult przodków nie zaistniał w systemach judeochrześcijańskich w takiej postaci jak w wymienionych wierzeniach. Jednak jego elementy znajdziemy także w prawosławnej doktrynie dotyczącej obcowania ze świętymi ${ }^{14}$, opartej między innymi na naukach Jana Złotoustego, zachęcającego do modlitw i pamięci o zmarłych. Podobną dogmatykę znajdziemy w katolickim przekonaniu opartym na doktrynie, iż na Kościół powszechny składają się trzy

${ }^{11}$ R. Ohly, Religie Afryki, w: Religie Azji, Afryki, Ameryki, Australii i Oceanii. Zarys dziejów, red. J. Keller, Iskry, Warszawa 1980, ss. 233-266.

${ }^{12}$ F. Avanzini, Religie Chin, tłum. K. Stopa, WAM, Kraków 2004, s. 37.

13 A. Ozga, Wizja zaświatów w folklorze i wierzeniach japońskich, „Gdańskie Studia Azji Wschodniej” 2019, nr 15, ss. 64-66.

14 A. Sarwa, Rzeczy ostateczne człowieka i świata. Eschatologia Kościoła Wschodniego, „Ravi”, Łódź 2002, ss. 93-107. 
wspólnoty: zbawiona (w niebie), walcząca (na ziemi) i pokutująca (w czyśćcu). Ta eklezjologia, oparta na wierze eschatologicznej, iż można pomagać przez modlitwę duszom czyśćcowym, choć jest innym wierzeniem niż afrykański czy szintoistyczny kult przodków, to jednak też utrzymuje, iż z duszami zmarłych można zachować pewną więź o charakterze duchowym ${ }^{15}$.

W ramach alternatywnej duchowości w kulturze zachodniej pojawiają się nowe odwołania do kultu przodków we współczesnych praktykach na granicy terapii i ezoteryki. Jedną z nich jest psychoterapia Berta Hellingera (przez kilkanaście lat misjonarza u Zulusów), wyraźnie zainspirowana wierzeniami afrykańskimi. W tym kierunku terapeutycznym utrzymuje się, że życie rodzinne jest bardzo ważne, ale jest też źródłem wielu problemów natury psychologicznej. Według Hellingera w idealnej rodzinie każdy ma swoje miejsce i rangę oraz prawo do przynależności. Problemem jest status osób, które zostały z jakiś powodów wykluczone bądź źle potraktowane w przeszłości rodzinnej. W rezultacie może dojść do tzw. uwikłania, czyli nieświadomej identyfikacji jednego z członków rodziny ze skrzywdzoną (i niekoniecznie żyjącą) osobą. To wymaga terapii i przywrócenia porządku w rodzinie, polegającego na harmonijnych relacjach rodzinnych. Ustawienia Hellingerowskie nie są terapią powszechnie uznawaną w środowiskach licencjonowanych terapeutów ${ }^{16}$.

W świetle zarysowanych przykładów religioznawczych i kulturowych można ulokować praktyki medialne związane z aplikacją Deep Nostalgia w ramach czegoś, co trzeba nazwać cyfrowym kultem przodków, choć bez wymiaru spirytystycznego i magicznego. Jest to nowe zjawisko, które spełnia część wyżej wymienionych kryteriów tradycyjnego kultu przodków. Przedmiotem zainteresowania użytkowników programu są na ogół zmarli bliscy z ostatnich kilku pokoleń. Dzięki „ożywieniu” fotografii więź emocjonalna ze zmarłą osobą zostaje przypomniana. Animowane twarze zmarłych mogą być digitalizowane i systematycznie odtwarzane w cyfrowych zasobach. MyHeritage, które stworzyło program, odwołuje się wprost do wartości rodzinnych, zachęcając użytkowników do reprodukowania zdjęć i filmików, a także ich rozpowszechnienia. W ten sposób budują się cyfrowe „plemiona”, które mogą szukać swoich wspólnych przodków, uśmiechających się do żyjących z ekranu urządzenia.

\section{Konsekwencje kulturowe nowych form mediatyzacji pamięci religijnej}

W naukach o kulturze czasami marginalia mogą zawierać coś, co jest interesujące z perspektywy badawczej. Zjawisko Deep Nostalgia jest egzemplifikacją takiej

${ }^{15}$ Cz. Bartnik, Dogmatyka katolicka, t. II, KUL, Lublin 2012, ss. 904-905.

16 J. Jagiełła, Metoda ustawień systemowych rodziny według Berta Hellingera w optyce analizy transakcyjnej, „Edukacyjna Analiza Transakcyjna” 2017, nr 6, ss. 316-324. 
sytuacji kulturowej, ponieważ aplikacja ta pozostaje raczej ciekawostką i osobliwością internetową, znaną głównie wytrawnym użytkownikom Internetu oraz osobom poszukującym narzędzi genealogicznych. Jednak technologia ta może budzić uzasadniony niepokój, ponieważ pojawia się możliwość sztucznego ożywania postaci zmarłych przez symulowanie ich ruchów głowy oraz gałek ocznych i ust. Można wyobrazić sobie dalsze możliwości rozwoju techniki, które będą jeszcze odważniejsze i bardziej realistyczne w próbach animowania pamięci o osobach zmarłych bliskich. Twórczość filmowa science-fiction zawiera już takie artystyczne imaginacje. Odcinek Be Right Back serialu „Black Mirror” (2013) zawiera historię o Marcie, która traci bliską jej osobę ${ }^{17}$. Po zmarłym Ashu zachowało się wiele nagrań w mediach społecznościowych. W bliskiej przyszłości możliwe jest jednak symulowanie nieżyjącej osoby w aplikacji, która realistycznie i wiernie odtwarza zachowanie zmarłego człowieka. W omawianym odcinku dochodzi do kolejnych kroków bohaterki, która w dążeniu do przywrócenia do życia Asha posuwa się do animowania jego inteligencji w bionicznym humanoidzie, który przypomina z wyglądu jej partnera. Z czasem dochodzi jednak do fabularnego rozczarowania zaawansowaną i futurystyczną techniką - pomimo wiernego realizmu odtwarzania zachowania i wyglądu nie udaje się osiągnąć efektu pełnego przywrócenia tożsamości nieżyjącego człowieka. Serial „Black Mirror” zawiera zatem etyczne przesłanie o ostrożności, jaką należy zachować wobec szybkiego postępu techniki i mediów, które będą w stanie zakwestionować istotę człowieczeństwa. Jak zauważa Mirosław Filiciak, motyw nostalgii, a zarazem lęku przed postępem jest obecny w filmach rozważających postęp techniki i kondycję ludzką ${ }^{18}$. John Lyden podkreśla, że choć nie da się przewidzieć dalszego postępu technik filmowych, to jednak póki ludzie będą mieli potrzebę zrozumienia duchowego, to wciąż będą sięgać do różnych źródeł wizualnych i fabularnych w popkulturze ${ }^{19}$.

Sięgając głębiej w historię kultury i mediów, warto rozważyć, czy obrazowi od początku nie towarzyszy refleksja tanatologiczna. Anna Zeidler-Janiszewska dzieli się refleksją, iż dzieje sztuki często przedstawiają portret jako coś, co powstaje lub aktualizuje się w obliczu śmierci, jako manifestacja potrafiąca przełamać koniec egzystencji. Jest to bardzo antropocentryczna wizja, w której człowiek jest „miejscem” obrazów. Koresponduje z nią założenie, że istota ludzka wytwarza i poznaje obrazy minione, próbując je sobie przypomnieć i nadać im osobiste znaczenie. Można tu mieć na myśli figuratywne przedstawienia ludzi z czasów sztuki malarskiej, w tym prehistorycznej, jak i sarmackie portrety trumienne z okresu nowożytności. Na tle

17 „Black Mirror”, Be Right Back, sezon 2, odcinek 4, 2013.

18 M. Filiciak, W parku rozrywki: granice mediów, w: Antologia tekstów polskiego kulturoznawstwa, red. P.J. Fereński, A. Gomóła, K. Moraczewski, Wydawnictwo Naukowe Katedra, Gdańsk 2017, s. 435.

19 J.C. Lyden, Film, w: The Routledge Companion to Religion and Popular Culture, red. J.C. Lyden, E.M. Michael Mazur, Routledge, London-New York 2015, p. 96. 
tych rozważań można przywołać opowieść o tym, iż kiedy w Afryce umiera jeden człowiek, razem z nim płonie jakby cała biblioteka jego obrazów i wspomnień20. Zatem obraz, także cyfrowy i zdigitalizowany, ma w sobie istotne podłoże somatyczne i cielesne, niejako konieczną substancję. Już sama fotografia i bez efektów „ożywiania”, które wyżej opisano, może powodować efekt iluzji, polegającej na tym, że gość z innego świata niejako „nawiedza” naszą teraźniejszość, przypominając właścicielowi zdjęcia o swoim dawnym istnieniu ${ }^{21}$.

Z mediatyzacją pamięci religijnej wiąże się ten aspekt, na który zwraca uwagę Marek Kaźmierczak, iż Internet w pewien sposób odziera pamięć z intymności detalu i szczegółu. Najbardziej zindywidualizowana pamięć może stać się elementem publicznym, utrwalonym w obrazie, podatnym na digitalizację, przetwarzanie i reprodukcję. Może to powodować rosnącą ahistoryczność tych obrazów, brak ciągłości linearnej ${ }^{22}$. Nie jest również przesądzone to, w jaki sposób odbiera te obrazy użytkownik - czy towarzyszy mu duchowy stan skupienia, czy raczej ludyczny stan konsumpcji kultury popularnej. Jeśli raczej to drugie odczucie, to wówczas może pojawić się wyczerpanie, a także znudzenie powtarzalnymi dziełami ${ }^{23}$. Niezależnie od tych rozważań z pewnością kontrola instytucji religijnych nad tymi przekazami jest bardzo ograniczona, gdyż treści te krążą w przestrzeni internetowej zupełnie swobodnie. W tym sensie można mówić o rozwoju religijności popularnej, rozwijającej się niezależnie od kościołów i wyznań24

Z perspektywy religioznawczej i kulturoznawczej plastyczność pamięci indywidualnej, która podlega mediatyzacji, można ulokować w ramach paradygmatu pamięcioznawczego. Historia pamięci w tym ujęciu podąża za rozwojem mediów. Kolejne wynalazki, takie jak druk, fotografia i media cyfrowe, wraz z procesami digitalizacji zmieniają mechanizmy funkcjonowania pamięci w kulturze. Aleida Assman wskazuje na to, że pamięć kulturowa służy przekazywaniu doświadczeń i wiedzy ponad granicami pokoleń. Prowadzi to do wytworzenia społecznej pamięci długoterminowej. Ten typ pamięci kulturowej opiera się na zewnętrznych mediach i instytucjach, zwłaszcza tych, które dbają o pamięć i przekazują wiedzę. Wymaga to przenoszenia doświadczeń, wspomnień i informacji na nośniki materialne. Pamięć kulturowa opiera się zatem na przekazywaniu złożonego repertuaru

${ }^{20}$ A. Zeidler-Janiszewska, Visual Culture Studies czy antropologicznie zorientowana Bildwissenschaft? O kierunkach zwrotu ikonicznego w naukach o kulturze, w: Antologia tekstów polskiego kulturoznawstwa, red. P.J. Fereński, A. Gomóła, K. Moraczewski, Wydawnictwo Naukowe Katedra, Gdańsk 2017, ss. 264-266.

21 M. Michałowska, Niepewność przedstawienia. Od kamery obskury do współczesnej fotografii, Wydawnictwo Naukowe WNS UAM, Poznań 2017, ss. 296-297.

22 M. Kaźmierczak, Auschwitz w Internecie..., ss. 204-205.

23 M. Michałowska, Niepewność przedstawienia..., s. 289.

24 J. Majewski, M. Kokoszczyńska, Religia - media - popkultura, Biblioteka Więzi, Warszawa 2020, s. 72; S. Sztajer, J. Drozdowicz, Changing Trajectories of Religion and Popular Culture. Cognitive and Anthropological Dimensions, LIT Verlag, Zurich 2018, ss. 95-103. 
heterogenicznych form symbolicznych. Mogą do nich należeć takie artefakty, jak teksty, obrazy, rzeźby czy miejsca związane z pomnikami, architekturą, określonym krajobrazem. Pamięć kulturowa według Assman służy do komunikacji w długofalowej perspektywie historycznej i ma szerszy charakter niż bardziej subiektywna pamięć zbiorowa. Wymaga medialnego i materialnego zakorzenienia. Pozostaje otwarta na wielość interpretacji i aktualizacje w określonym czasie i doraźnej perspektywie. Zdaniem badaczki do istoty pamięci kulturowej należy napięcie między pamiętaniem a zapomnieniem, tym, co widoczne, i tym, co utajone. W związku z tym pamięć kulturowa ma przynajmniej dwa poziomy architektury ${ }^{25}$.

Próbowano zatem wskazać różne formy pamięci kulturowej. Do jednych z nich należy pamięć magazynująca. Jest to rodzaj pamięci archiwizującej. Mieszczą się w niej fakty i wiedza historyczna, które nie znajdują się w danym momencie w polu uwagi praktyk upamiętnienia. Współczesne magazyny pamięci, dzięki rozwojowi mediów, a także digitalizacji, są bardzo pojemne, a dostęp do nich jest coraz łatwiejszy. Zasoby pamięci magazynującej mogą ulec zapomnieniu, ale w sytuacji gdy następuje ich wydobycie, ten rodzaj pamięci zmienia się dialektycznie w pamięć funkcjonalną.

Pamięć funkcjonalna, zwana inaczej pamięcią zamieszkałą, jest również Assmanowskim konstruktem. Pojawia się wtedy, gdy aktywują się i ożywiają w społecznej praktyce informacje na temat określonych wydarzeń czy postaci z przeszłości. Magazyn pamięci przestaje być tylko przechowalnią faktów historycznych, niemających kulturowego znaczenia dla współczesnej tożsamości. Zakres pamięci funkcjonalnej jest węższy niż pamięci magazynującej. W tym pierwszym typie znajdują się tylko wybrane i stale przypominane wydarzenia $\mathrm{z}$ historii danej grupy ${ }^{26}$.

Adam Rajewski zauważa, że w paradygmacie pamięcioznawczym samej kategorii pamięci nie traktuje się jako obszaru przeznaczonego tylko dla nauk psychologicznych i medycznych. Z perspektywy kulturoznawczej i religioznawczej istotne jest, aby prowadzić badania nad pamięcią, uwzględniając społeczno-kulturowe wpływy otaczającej nas rzeczywistości. W tym bowiem ujęciu pamięć kształtuje się w jednostce przez wzrastanie w danej społeczności, oddziałującej na nie przez różne zewnętrzne procesy. Indywidualne wspomnienia są tylko częścią większej pamięci, która jest zależna od grupy, którą może być naród, wspólnota religijna i inne byty społeczne. Tak rozumiane zasoby pamięci podlegają transmisji przez akty komunikacji. Własne wspomnienia człowieka ożywiane są przez kontakt ze światem zewnętrznym, ale podlegają wielu wpływom innych ludzi i relacji osób oddziałujących na jednostkę. Jeśli podążyć tym tropem Rajewskiego, wszelkie wspomnienia biorą swój początek w myśleniu zbiorowości, do których jednostka

${ }^{25}$ A. Assman, Między historiq a pamięciq̨. Antologia, Tłum. M. Saryusz-Wolska, Wydawnictwa Uniwersytetu Warszawskiego, Warszawa 2013, ss. 55-57.

${ }^{26}$ Ibidem, ss. 325-326. 
przynależy ${ }^{27}$. Pamięć tak rozumiana jest wytworem nie natury, ale kultury, czyli tego, co społeczność, w toku międzypokoleniowego trwania i komunikacji, wytwarza i podtrzymuje. Tak również może dziać się z pamięcią mediatyzowaną w ramach projektu Deep Nostalgia.

\section{Zakończenie. Między sekularną a religijną pamięcią}

Danièle Hervieu-Léger zauważa, że w ramach mediatyzacji następuje zmiana statusu pamięci w kulturze. Rozwijając myśl badaczki, można zauważyć, że możliwość natychmiastowej transmisji obrazów z każdego zdarzenia na świecie oraz epatowanie widzów różnymi przesyconymi newsami powoduje ich eventowość (zdarzeniowość). Chwilowość tych wydarzeń wiąże się z brakiem możliwości bezpośredniego ustosunkowania się widza do wydarzeń odległych. Rozczłonkowany, zmediatyzowany świat nie sprzyja jednocześnie strumieniu, który podążyłby w jednym, uporządkowanym kierunku holistycznej pamięci zbiorowej. Można tu nawet mówić o powstaniu pamięci anomicznej, na którą składają się strzępki wspomnień oraz fragmenty informacji, których nie można spójnie powiązać w jedną, czytelną całość $^{28}$. W rezultacie można sformułować również w ujęciu Hervieu-Léger drugą skłonność plastycznie wpływającą na inne postrzeganie pamięci w społeczeństwie nowoczesnym. Jest to fragmentacja w nieskończoność pamięci jednostek i grup. Rozszerzenie osobistego doświadczenia odgrodziło jednocześnie dostęp do zasobów wspólnej pamięci społecznej. To zjawisko rozdrobnienia przestrzeni, czasu i instytucji w sieć wspomnień, których czas trwania jest zbyt krótki i efemeryczny, aby mogły być utrwalone - są niemal niszczone w tym samym momencie, w którym powstają. W rezultacie pamięć zbiorowa nowoczesnych społeczeństw ma postać raczej okruchów i kawałków.

W refleksjach Hervieu-Léger można mówić o powiązaniu między religią a pamięcią w zsekularyzowanym społeczeństwie, polegającym na wyczerpywaniu się pamięci. Jednak podobnie jak wciąż kwestią dyskusji jest stopień zaawansowania sekularyzacji w Europie i w Polsce, tak rzeczą otwartą jest poziom zużycia pamięci religijnej w kulturze. Autorka sugeruje możliwość wytworzenia się pamięci substytucyjnych, które są różnorodne i cząstkowe, ale jednak zachowujące przynajmniej w części możliwość zbiorowej identyfikacji bądź społecznej więzi. Społeczeństwo nowoczesne cechujące się skłonnością do zmian oraz dynamiką kulturową może mimo to zachowywać pewne odruchy „odwołań do pamięci”. Jeśli zachodzą takie postawy, wyraża się to w wyobrażeniowym ożywieniu przeszłości, na której zdaniem Hervieu-Léger opiera się tożsamość zarówno zbiorowa, jak i jednostki ${ }^{29}$.

27 A. Rajewski, Rozważania na temat Assmannowskiej teorii pamięci, „Rocznik Antropologii Historii” 2013, nr 1(4), ss. 187-202.

${ }^{28}$ D. Hervieu-Léger, Religia jako pamięć, tłum. M. Bielawska, Nomos, Kraków 1999, s. 174.

${ }^{29}$ Ibidem, s. 191. 
W odróżnieniu od dawnych i tradycyjnych społeczeństw, które bezpośrednio opierały się na pamięci, w kulturze nowoczesnej potrzebne jest pobudzanie danej pamięci, do czego asumpt daje ogólna niepewność znaczeń, jak i potrzeba zakotwiczenia się w gąszczu pluralistycznych i różnych aksjologii współczesności. Wynikać to może również z konieczności posiadania minimalnego wspólnego świata wyobrażeń ciągłości, aby można było myśleć o wspólnej przyszłości w danym społeczeństwie.

\section{Literatura}

Assman A., Między historiq a pamięciq. Antologia, tłum. M. Saryusz-Wolska, Wydawnictwa Uniwersytetu Warszawskiego, Warszawa 2013.

Avanzini F., Religie Chin, tłum. K. Stopa, WAM, Kraków 2004.

Bartnik Cz., Dogmatyka katolicka, t. II, KUL, Lublin 2012.

Briggs A., Burke P., Społeczna historia mediów. Od Gutenberga do Internetu, tłum. J. Jedliński, Wydawnictwo Naukowe PWN, Warszawa 2015.

Campbell H.A., When Religion Meets New Media, Routledge, London-New York 2010.

Filiciak M., W parku rozrywki: granice mediów, w: Antologia tekstów polskiego kulturoznawstwa, red. P.J. Fereński, A. Gomóła, K. Moraczewski, Wydawnictwo Naukowe Katedra, Gdańsk 2017.

Hervieu-Léger D., Religia jako pamięć, tłum. M. Bielawska, Nomos, Kraków 1999.

Hudzik J.P., Wykłady z filozofii mediów, Wydawnictwo Naukowe PWN, Warszawa 2017.

Ilnicki R., Filozofia i science fiction: technoanamneza, Wydawnictwo WNS UAM, Poznań 2014.

Iwanicki J., Memofania kultury. Zjawisko memów religijnych, „Humaniora. Czasopismo Internetowe” 2018, nr 1(21).

Jagiełła J., Metoda ustawień systemowych rodziny według Berta Hellingera w optyce analizy transakcyjnej, „Edukacyjna Analiza Transakcyjna” 2017, nr 6.

Kawecki W., Zobaczyć wiarę. Studium obrazu postrzeganego jako komunikacja wiary z perspektywy teologii kultury i teologii mediów, Homo Dei, Kraków 2013.

Kaźmierczak M., Auschwitz w Internecie. Przedstawienia Holokaustu w kulturze popularnej, Wydawnictwo Naukowe UAM, Poznań 2012.

Lyden J.C., Film, w: The Routledge Companion to Religion and Popular Culture, red. J.C. Lyden, E.M. Michael Mazur, Routledge, London-New York 2015.

Majewski J., Kokoszczyńska M., Religia - media - popkultura, Biblioteka Więzi, Warszawa 2020.

Sztajer S., Drozdowicz J., Changing Trajectories of Religion and Popular Culture. Cognitive and Anthropological Dimensions, LIT Verlag, Zurich 2018.

Michałowska M., Niepewność przedstawienia. Od kamery obskury do współczesnej fotografii, Wydawnictwo Naukowe WNS UAM, Poznań 2017.

Ohly R., Religie Afryki, w: Religie Azji, Afryki, Ameryki, Australii i Oceanii. Zarys dziejów, red. J. Keller, Iskry, Warszawa 1980.

Ozga A., Wizja zaświatów w folklorze i wierzeniach japońskich, „Gdańskie Studia Azji Wschodniej” 2019, nr 15. 
Rajewski A., Rozważania na temat Assmannowskiej teorii pamięci, „Rocznik Antropologii Historii” 2013, nr 1(4).

Sarwa A., Rzeczy ostateczne człowieka i świata. Eschatologia Kościoła Wschodniego, „Ravi”, Łódź 2002.

Tracewicz K., Media a religijność i moralność badanej młodzieży, Wydział Teologii Uniwersytetu Warmińsko-Mazurskiego w Olsztynie, Olsztyn 2015.

Zeidler-Janiszewska A., Visual Culture Studies czy antropologicznie zorientowana Bildwissenschaft? O kierunkach zwrotu ikonicznego w naukach o kulturze, w: Antologia tekstów polskiego kulturoznawstwa, red. P.J. Fereński, A. Gomóła, K. Moraczewski, Wydawnictwo Naukowe Katedra, Gdańsk 2017.

\section{Źródła internetowe i filmowe}

10 Historical Personalities Animated with Deep Nostalgia, http://www.youtube.com/watch?v=251pfVoGBUA [dostęp: 6.30.2021].

MyHeritage, https://www.myheritage.pl/deep-nostalgia [dostęp: 6.30.2021].

„Black Mirror”, Be Right Back, sezon 2, odcinek 4, 2013. 
